\section{United States Expansionism and the Pacific}

Pacific islands have long figured as idylls a myth that conceals a history of Western entanglement ranging from voyages of discovery, competition for trade routes, and colonial expansion, to annexation, commercial exploitation, militarisation, population displacement, and dozens of nuclear weapons tests (as recently as 1996).

As early as the I6th century, Western encounters with Pacific peoples were marked by cultural misunderstandings and frequent violence, as is well documented in both Antonio Pigafetta's account of Magellan's major exploring voyage (I52I) and Pedro Fernández de Quirós's journal relating Mendaña's failed attempt to colonise the Solomons (I595). By the I8th century, European voyages of exploration and scientific documentation, with their vivid accounts, established the South Seas both as a real site ripe for economic and territorial expansion, and an ideal space suited to the projection of desires for escape, spatial mastery, and sensual indulgence.

By the I770s, the US had started to bring its free-market values to the Pacific, when ships from the East Coast sailed around Cape Horn, heading for the trans-oceanic Chinese trade routes laid down by Spain, France, and Britain. David N. Leff notes that the American flag first reached China in 1784 , establishing a strategic goal that would dominate USPacific relations (Leff 1940: 3). Spurred on by an expansionism born in the 18 th century and soon harnessed to the Igth-century ideology of manifest destiny, the roots of the 'American Pacific' were grounded in the interconnected forces of real politics and mythic invention.

One of first colonising gestures made by the recently decolonised US nation took place in I79I, when Joseph Ingraham of the Hope claimed the northern islands of the Marquesas, naming them after luminaries of the US Enlightenment such as Franklin, Adams, and Hancock. Just three weeks later, Etienne Marchand reclaimed all of the Marquesas for France. Significantly, the Marquesas would become the site of the first major US military conflict in the Pacific, when Captain David Porter - sometimes called 'the first American imperialist' (Rowe
2000: 83) - stopped at Taiohae harbour in Nukuhiva to refit his ship the Essex during the War of I8I2. The I8I2 war, as Thomas Walter Herbert notes, evinced a desire of the US to be recognised as a legitimate state, one of the 'community of nations' (Herbert I980: 79), as Porter's actions in the Marquesas seem to bear out. Following a breakdown of agreements with local people, Porter and his men became embroiled in ongoing conflicts between the Tei'i, Hapa'a, and Taipi peoples, and proceeded to raid Taipivai, burning whole villages and killing many of what Porter later described as its 'unhappy and heroic people' (Porter I822: I05). Porter formally took possession of the island, demanding that its people swear allegiance to the American flag. His subsequent 'Declaration of Conquest' indicates the paternalism of a US Enlightenment vision:

Our rights to this island being founded on priority of discovery, conquest, and possession, cannot be disputed. But the natives, to secure themselves that friendly protection which their defenseless situation so much required, have requested to be admitted into the great American family, whose pure republican policy approaches so near their own. (79)

The US government never ratified Porter's occupation, and 30 years later the French again claimed the island group. Still, Porter's 'Typee War' marked the fierce impact of haole (outsiders) on Pacific locales, and it fascinated and haunted travellers in Polynesia (such as Herman Melville and Paul Gauguin) for years to come.

In spite of Porter's failures, his published account, along with others that appeared around the same time (the German-Russian circumnavigator Adam J. von Krusenstern's Voyage round the World in the Years $1803 \ldots 1806$ appeared in English in $18 \mathrm{I}_{3}$, and his chief scientist, Georg H. von Langsdorff, published Voyages and Travels in Various Parts of the World in English in $\mathrm{I}^{8} \mathrm{I}_{3}-\mathrm{I} 4$, with a US edition in 1817 ) helped reinforce a notion that Pacific islands could serve US interests. However, while accounts such as Porter's painted a relatively positive portrait of Pacific cultures and stressed connections between the Marquesas and the 'great American family', there were other, more derisive images 
of Pacific life that undermined any sense of familial inclusion. Missionary reports written under the influence of Calvinist doctrine commonly figured Pacific islanders as cruel, violent, and needing religious conversion. Publications that backed missionary societies (such as the Massachusetts Baptist Missionary Magazine and Niles Weekly Register) were dedicated to 'evangelizing the heathen', and they portrayed groups such as the Maoris and Society Islanders as indulging in warfare, orgies, cannibalism, and infanticide. These 'hard primitivist' notions of barbaric savagery thus accompanied, and in many ways played off, 'soft primitivist' concepts of noble savages inherited from European thinkers such as Jean-Jacques Rousseau; together they are emblematic of an underlying duality that has persisted in US representations of the Pacific.

Charles Wilkes's US naval expedition of 1838-42 further manifested this contradictory stance: purporting to be objective and scientific, Wilkes would become better known for his strong-arm military tactics (much like Porter's before him) than for his contributions to enlightened American progress. During an aggressive campaign in Fiji on Malolo, the villages of Arro (now Yaro) and Sualib were burned to the ground as revenge for the killing of two officers in the midst of a trading dispute. At Wilkes's command, injured survivors crawled on their hands and knees, begging for his pardon. One of Wilkes's crew, Charles Erskine, was so stunned by the events that he wrote: 'perhaps I may be pardoned for thinking it would have been better if the islands had never been discovered by Europeans; not that Christianity is a failure, but that our [Western] civilization is' (quoted in Perry 1994: 52-53).

The political and commercial contours of the 'American Pacific' era began to emerge with the help of the British-Chinese Opium War and the Treaty of Nanking in I842. The US found itself in a disadvantaged position regarding Pacific trade routes due to concessions granted to Britain, but lobbied for extended rights and therefore achieved a stake in the Pacific on a par with European powers. Soon after, the signing of the Oregon Treaty in 1846 signalled the coming of the 'American Pacific empire', when US freemarket liberalism would supplant established European powers (Dudden 1994: xix). In I850, California was declared the 3ist state in the Union, and the vaunted ideology of manifest destiny effectively became a geopolitical reality. As the balance of power shifted west, California became central to Pacific trade, with the west coast now at the heart of 'the global space economy of capitalism that would continue for the next century and a half' (Soja I989: 190). Closely linked to these economic shifts was the growth of US whaling routes, which Porter had staunchly defended. By midcentury, the importance of whaling was manifested in the US presence and investment in Hawai'i: the commercial plantation periphery to the emerging global centrality of the US.

The work of the literary figure perhaps most closely associated with the whaling industry, Melville, offers insights into some of the anxieties raised by US expansionism. Melville's Typee (I846) gestures towards anti-interventionism, and questions fundamental assumptions behind Western cultural hierarchies:

The enormities perpetrated in the South Seas upon some of the inoffensive islanders well nigh pass belief. ... We breathe nothing but vengeance, and equip armed vessels to traverse thousands of miles of ocean in order to execute summary punishment on the offenders. On arriving at their destination, they burn, slaughter, and destroy, according to the tenor of written instructions, and sailing away from the scene of devastation, call upon all Christendom to applaud their courage and their justice. How often is the term 'savages' incorrectly applied! (Melville I996/1846: 27)

Melville's ironic reversals threaten to turn the logic of the imperial 'civilising mission' on its head. By the time of writing Moby-Dick (I85I), Melville had outlined an even clearer sense that the growth of the American Pacific would engender not just tactical violence, but ongoing commercialism, culminating in an Oceanic domination where 'new built California towns, but yesterday planted by the recentest race of men' would be directly linked to 'low-lying, endless, unknown Archipelagoes, and impenetrable Japans' via islands overrun by the demands of US markets (Melville I994/185I: 456).

Driven by market forces, US expansion after the I85os was largely linked to demands for guano, a highly profitable commodity used as fertiliser. With the 'Guano Wars' and Guano Act of I856, Washington's leaders declared the legality of claiming territory in the name of commerce: 
Whenever any citizen of the United States discovers a deposit of guano on any island, rock, or key, not within the lawful jurisdiction of any other Government, and not occupied by the citizens of any other Government, and takes peaceable possession thereof, and occupies the same, such island, rock, or key may, at the discretion of the President, be considered as appertaining to the United States. (quoted in Leff I940: 7-8)

Unincorporated territories such as Baker, Jarvis, Nikumaroro (Gardner), Fakaofo (Bowditch), and Howland islands, along with Kingman Reef and the Kalama (Johnston) Atoll, were taken under this provision. At the same time, copra (dried coconut for producing oil) was emerging as the primary industry in the region, with Germany holding the greatest stake. Increasing commercial competition over the coming decades had substantial effects on Pacific and migrant labourers, with blackbirding (kidnapping indigenous peoples into slave labour) increasing through the I86os.

As the commercial stakes got higher, a more clearly defined agenda emerged under Abraham Lincoln's secretary of state William Henry Seward, who envisioned the Pacific as central to the quest to develop a US 'empire' that could gain control of world markets. Seward argued that the US could achieve global power through commercial competition, 'depending not on armies nor even on wealth, but directly on invention and industry' (quoted in Paolino 1973: 4). Though Seward's wider ambitions were never realised during his lifetime, shortly after the end of the Civil War, in 1867 , he was responsible for bringing both Alaska and the Midway Islands under US control.

It has often been argued that as late as the I88os, Washington was still exhibiting an ambivalent attitude towards undertaking extensive expansion in the Pacific. The US stake could be seen as meagre compared to European colonial networks', and its interests were largely limited to those of private shippers and traders. Donald Johnson and Gary Dean Best note that in the I86os, Apia, Lauthala, Suva, and Papeete had US consular representatives, but even these numbers began to dwindle as France, Britain, and later Germany assumed control of various island groups. Though this diminished presence might be attributed more to the recovery period after the Civil War and the economic crash of 1873 , rather than to a lack of official interest, Johnson and Best (1995: 123) argue that 'there simply was no American colonial policy in the I870s and I88os, either in Congress or in the executive branch, although occasionally voices might be raised in favor of one or another expansive move'.

A closer look, however, indicates that the US was hardly turning away from Pacific speculation but instead shifting focus onto a small number of strategic island sites. For Walter LaFeber, the years $1850-89$ can be viewed as the 'roots of empire', a period of preparation for the imperial acquisitions of the I8gos (LaFeber I998/I963: 55). US representatives successfully negotiated in 1872 for the use of the harbour at Pago Pago, and the close involvement of Albert B. Steinberger (a self-styled 'special agent' of the US State Department who came to see himself as the future 'arch-manipulator' of Samoan affairs) in the formation of a Samoan government in 1875 assured ongoing US influence in the midst of subsequent governmental power shifts (Davidson I967: 60). By I878, US interests were officially entangled in Samoa, and by the late I88os the secretary of state, Thomas Bayard, was explicitly linking the US interest in Samoa to the strategic construction of a canal across Central America. It is not really possible, therefore, to separate the interconnected US designs on the Pacific, Latin America, and the Caribbean. During this period, advocates of 'preventive imperialism' urged for the acquisition of territories that were in danger of being taken by other nations, while illicit activities such as blackbirding continued unabated.

Historians have contested the once commonly held notion that US imperial expansion during the i89os should be seen as an aberration amid predominantly isolationist policies. Indeed, the scale of the events that took place over an I8-month period between I898 and I899 (when the US took possession of Hawai'i, the eastern islands of Samoa, Wake Island, Guam, the Philippines, Puerto Rico, and Cuba, the latter as an occupied country and protectorate) suggests that these actions were hardly isolated or anomalous. In Hawai'i, Queen Liliuokalani was overthrown in 1893 by American forces as a direct result of increasing commercial exploitation of the sugar industry, but the act was not a fait accompli. Grover Cleveland's investigation, 
the Blount Report of July 1893 , found that US forces had conspired against the monarchy, and Cleveland opposed annexation due to the islanders' resistance. The subsequent Morgan Report of I894, however, reversed Blount's conclusions and refused Liliuokalani's return to power, leading to an interim colonial administration headed by an open enemy of Hawai'ian self-rule, Sanford B. Dole. President William McKinley, who took office in 1897 , also favoured annexation. In I898, he succeeded, arguing: 'we need Hawaii just as much and a good deal more than we did California. It is manifest destiny' (quoted in Morgan 2003: 225).

A member of the US Civil Service Commission, John R. Procter, summed up the momentous events:

The year 1898 will be one of the epochmarking years in the history of the United States. In this year is to be decided the great question of whether this country is to continue in its policy of political isolation, or is to take its rightful place among the great World-Powers, and assume the unselfish obligations and responsibilities demanded by the enlightened civilizations of the age. (quoted in Welch 1972: 2I)

Procter invoked a 'New Imperialism' rising from the ashes of European imperialism, and the Pacific was seen as the natural extension of manifest destiny. For pro-imperialists such as Procter, the issue was not merely political, but also moral and even explicitly racial. Procter's invocation of battles in the Philippines praises the systems developed by 'Teutonic ancestors', finding them regenerated in US beliefs and practices: 'from the blood of our heroes, shed at Santiago and Manila, there shall arise a New Imperialism, replacing the waning Imperialism of Old Rome; an Imperialism destined to carry world-wide the principles of Anglo-Saxon peace and justice, liberty and law' (quoted in Welch I972: 26). Indeed, as Peter Hulme argues, 'as the nineteenth century progressed, US Americanism increasingly became an ideology based on the supposed moral and political superiority of the Anglo-Saxon peoples' (Hulme 20I2: 59), a concept reinforced in a closely related notion of 'English-speaking peoples'. This privileged category was promoted in the writings of Teddy Roosevelt (the first volume of his The Winning of the West is titled 'The Spread of the English-Speaking Peoples') and later persisted in prominent works such as Winston Churchill's A History of the English-Speaking Peoples.

The motives behind expansionism were summed up by McKinley: 'there was nothing left for us to do but to take them all and to educate the Filipinos and uplift and civilize and Christianize them, and by God's grace do the very best we could by them as fellowmen for whom Christ also died' (quoted in Dudden 1994: 84). With these objectives, the president placed what Kipling had ironically labelled the 'white man's burden' firmly into US hands, perpetuating and extending established European colonial networks. Vincent Rafael reminds us that the Philippines mission was characterised by McKinley's policy of 'benevolent assimilation', which incorporated a nostalgic vision of manifest destiny while at the same time patronising Filipinos as the colonial children of the US, separating out the good ones from those labelled 'insurgents' (Rafael 2000: 2I-22). More than 200,000 Filipinos (perhaps as many as a million) were killed during the ensuing Philippine-American war.

Often represented as a benevolent mission, US expansionism was underpinned by political and economic motives. For example, the watershed year of 1898 would see the founding of the American Asiatic Association, with its mission of working to 'foster and safeguard American trade and commercial interests' (i.e. to lobby to protect US trade routes across the Pacific) and to 'co-operate with religious, educational, and philanthropic agencies designed to remove existing obstacles to the peaceful progress and wellbeing of Asiatic peoples' (American Asiatic Association 1925: 709). In 1899, the Association's secretary pushed aside prevailing messages about the 'civilising mission' and offered a blunter analysis of the Philippines' annexation: 'had we no interests in China', he noted, 'the possession of the Philippines would be meaningless' (quoted in LaFeber 1998/1963: 4I0).

There were, nonetheless, open concerns regarding the annexations of $1898-99$. The Philippines conflict, for example, led antiimperialists such as William James to argue that any possibility of the US retaining a moral advantage in international politics was lost: 'now (having puked up our ancient national soul after five minutes reflection, 
and turned pirate like the rest) we are in the chain of international hatreds, and every atom of our moral prestige lost forever'. For James, the debate over expansion in the Pacific was 'surely our second slavery question' (James I972/I900: I08-IO9), pointedly collapsing the presumed gap between far-flung imperialist aggressions and domestic racial policies by highlighting continuities between 'external' and 'internal' (or 'foreign' and 'domestic') subjugations.

Advocates for expansion nonetheless were gaining the upper hand in the war of rhetoric, arguing that what once had appeared to be limitless space for advancement within US borders was filling up. The transcontinental railroad, completed in I869, had shrunk spatial perceptions of the continent dramatically, reducing the travelling time from the East Coast to California from an arduous journey of months to one that could be done in under a week. Furthermore, by I89o, the US Census Bureau would announce that the western frontier had officially closed. A range of scholarly and literary works began to lament the loss of free land, indicating that a pervasive 'frontier crisis' had entered US consciousness (Wrobel I993: 29). At the same time, rapid industrial expansion contributed to 'boom and bust' economics: depression struck in $1873-78$ and $1882-86$, and would return with force in 1893 , lasting through I897. Rekindling the visionary thinking of empire-builders like Seward, historian Hubert Howe Bancroft laid out plans for escaping what appeared an increasingly urbanised and unstable American continent by reinvigorating manifest destiny across 'the new Pacific':

The year 1898 was one of bewildering changes ... Almost since yesterday, from the modest attitude of quiet industry the United States assumes the position of a world power, and enters, armed and alert, the arena of international rivalry as a colonizing force, with a willingness to accept the labour and responsibilities thence arising. (Bancroft I9I2: $\mathrm{I}_{2}-\mathrm{I}_{3}$ )

Bancroft then envisions the new America: 'Thus the old America passes away; behold a new America appears, and her face is toward the Pacific!' (ibid.)

Yet the shift of US military and commercial power towards the Pacific was not merely the logical extension of the westward march of empire; it can be seen as part of the socio-spatial dynamics that Rob Wilson (drawing on Edward Soja) has called 'peripheralization', where the spatial mastery and centralisation of one area becomes yoked to the commodification and distribution of power over peripheral areas. Hence Pacific islands like Hawai'i become linked as plantation and tourist resources to the growth of California as part of a closely integrated 'global dynamic' (Wilson 2000: 94). This period further encompassed the rise of what Emily Rosenberg calls the ideology of liberaldevelopmentalism in US diplomatic policy: the adaptation of free-market enterprise as a fundamental principle for all nations, coupled with the growing acceptance of government intervention to protect private enterprise and speculation abroad. This ideology was aligning itself with both religious and secular senses of the US 'mission' overseas: the Christianisation of non-Christians through radical conversion and the bringing of technological and professional know-how, or 'progress', to 'underdeveloped' peoples around the globe (Rosenberg I982: 7-9).

By the start of the 2oth century, New World powers such as Australia, New Zealand, and Japan, like the US, were jockeying for position in the Pacific amidst established European colonial powers. It was thus hardly surprising when, in 1907, a rumour circulated that the US wanted to buy Tahiti from France for $\$ 5$ million, presaging the 'dollar diplomacy' that would shortly hold sway under William Howard Taft's Administration. With the Panama Canal's completion in I9I4 (after Panama, backed by the US warship Nashville, declared its independence from Colombia in early 1904), the US gained an enormous advantage in the global commercial arena. Powers such as France (their own canal project having foundered) had long held that the canal was the lynchpin to gaining dominance over Pacific trade routes. The French journal Océanie française stated: 'The Panama Canal is not only an instrument of economic conquest. The Panama Canal will also create incalculable consequences. It will permit an active reaffirmation of the Monroe Doctrine, altered from its original intent now for the sole profit of the Americans' (quoted in Aldrich I990: 26I). The French clearly still felt the sting of the Monroe Doctrine's invocation which, starting in 1842 , had prevented intervention in protectorates such as Hawai' $i$. 
US investment abroad, both economic and psychic, proceeded apace: between I897 and I9I4 (before the First World War forced a temporary slowdown), US direct investments in overseas companies increased fourfold, while the immense popularity of missionary societies like the YMCA, 'rushing to convert the world to American-style Christianity within their lifetimes', continued to gain ground (Rosenberg 1982: 28). When the War came, it did not spare the Pacific: in I9I4, Australian troops fought German and Melanesian soldiers in New Guinea, while soon after, a German ship bombarded Tahiti, rather than Samoa, due to the 'high esteem' German naval commanders held for its population (Hiery 2012: 23-27). The Pacific, the strategic crossroads of competing powers, would in just over 20 years' time end up as a theatre of war, where the simmering imperial conflicts would be fully acted out.

Robert Aldrich refers to the period between the World Wars as the apogee of colonial power in the Pacific: a time when the idea of colonialism reached its zenith, when expansionist lobbyists and new modes of technical reproduction were disseminating images of colonial ideology more widely than ever before (Aldrich I990: 273). But tensions were visible: the policies of New Zealand administrator Brigadier General George Spafford Richardson in Samoa initiated the rise of the anti-colonial movement the Mau (Samoan for holding fast), with violent skirmishes between New Zealand police and Mau protestors in the late I920s. The Mau movement was also active in American Samoa, which was still under US Navy rule (Margaret Mead, famously, lived in a Naval dispensary with an American family while researching Coming of Age in Samoa [1928]). Under US rule, Samoans still faced the prohibition of interracial marriage, and there were disputes relating to pay for workers in the copra trade and Samoan police guard. In I929, in response to direct Samoan pressures, the US government changed the status of the territory from that of an 'illegal' to a 'legal' colony (Droessler 2013: 62).

As the Great Depression hit, US expansionism appeared to slow in terms of markets and territorial acquisitions, but at the same time tourism was helping to propagate the Pacific idyll in the popular imagination: by the I930s, unprecedented numbers were embarking on luxury ships for 'round the world' cruises. Pacific crossings included stopovers at ports that had long underpinned imperial trade networks. The establishment of Matson Lines' famous 'white ships' (the S.S. Malola was launched in 1927 and the S.S. Mariposa in I93I) linked the east and west coasts of the US, via the Panama Canal, to Hawai'i, Samoa, Fiji, New Zealand, and Australia, reflecting the escalation of mass tourism and a substantial increase in tourist traffic through Pacific ports (the 'white ships' perhaps echoing Theodore Roosevelt's Great White Fleet of battleships, also painted white, sent to circumnavigate the globe in 1907 in a show of US military prowess). At the same time, commercial air travel was becoming a feature of modern life: in 1935, Pan American Airlines began services between San Francisco and Manila, with the China Clipper airplane becoming a symbol of national pride.

US military expansion also continued. The Panama Canal was widened in the midr93os to accommodate larger warships, and military installations on key sites such as Samoa were further developed, with the construction of a naval airbase and advanced fortifications at Pago Pago harbour in 1940. When the Japanese attacked Pearl Harbor on 7 December I94I, the US immediately entered the Second World War; within days, thousands were flooding army recruitment stations to enlist for war, reflecting the powerful military, territorial, and psychic roles that Pacific island territories were playing in US life. Strategic planning in the run-up to war would prove enormously beneficial, when island bases served as supply sites and staging grounds for years of fierce air, sea, and land battles (a period of total militarisation of the 'Pacific theater' of war) as the US and its allies battled Japan for Pacific mastery. As Rob Wilson notes, the idea of the 'American Pacific' began to take root as early as imperialist struggles for Samoa and Hawai'i during the late igth century, but it was realised only after these Second World War battles, when the US defeated Japan and took control via 'strategic trust' in Micronesia and other territories of interest (Wilson 2000: 106).

Immediately following the war, the psychic hegemony of the American Pacific was so complete that James Michener's Tales of the South Pacific (1947) could represent the Pacific's 'trivial islands' as essentially nostalgic playgrounds for American soldiers and their 'native' love interests (quoted in 
Lyons 2006: 28). The new 'American Pacific' became the sum of a US vision won through commerce, missionary work, and ultimately military conflict on an unprecedented scale. As constructed after the post-war seizing of territories from Japan, it came to include the Marshall Islands, Belau, the Federated States of Micronesia, the Northern Marianas, Guam, and American Samoa. As of 1990 , there were nearly 300,000 US military personnel based in the 'Pacific theater', with the Department of Defense spending roughly $\$ 16.8$ billion (US) to support its presence there (United States Government Accountability Office I99I). This military presence remains the war's most profound and controversial legacy, with whole islands having been used as test sites for nuclear arms, and others (such as Kalama Atoll) becoming military dumps for chemical weapons. At least 66 nuclear tests were conducted in the Bikini Atolls, held under the unprecedented legal arrangement of a 'strategic trusteeship'. Moved to make way for 'Operation Crossroads', the first detonation of a nuclear device since the bombing of Nagasaki, the people of Bikini would experience a series of displacements that enacted severe physical and emotional hardships. They were moved to Rongerik Atoll, where mass starvation ensued, then to Kwajalein Atoll, living in tents alongside a military airstrip, and then finally to Kili Island, a tiny outpost without a lagoon for fishing, hence inadequate for supplying food. The majority remain there due to residual nuclear contamination.

The story of the Bikini islanders exemplifies the economic dependency, environmental degradation, and military dominance that still mark the US presence in the Pacific. In spite of their cultural richness, economic hardship (unemployment in American Samoa approaches 30 per cent) in various territories has led to an unusually high proportion of people seeking work in the US armed forces, with disproportionately high casualties in recent wars as a result (American Samoa has its own military recruiting station in Utulei). In unincorporated territories such as American Samoa and Guam, there are ongoing calls for political representation with full US voting rights, as well as movements calling for greater political autonomy, and independence.

Saleable terms such as the 'Pacific Rim' and transnational 'Asia-Pacific' markets have begun to absorb and supplant concepts such as the American Pacific. Fijian writer
Subramani (1985) has argued that even a seemingly monolithic term like 'American Pacific' has nonetheless long formed part of a broader, multicentred Pacific region that speaks to and has confronted a range of imperial centres. Works such as Vanessa Warheit's and Amy Robinson's film (and internet blog) The Insular Empire (2010), made in the Marianas, has addressed related issues of the paradoxes of presumed isolation versus actual transnational and transcultural interactions, charting everyday life in the still largely ignored spaces of empire. Barack Obama, raised in Hawai'i and hence, as Holger Droessler puts it, 'America's first Pacific President', declared in a speech to Japanese leaders in November 2009 that the United States 'is a nation of the Pacific; Asia and the Pacific are not separated by this great ocean, we are bound by it'. The centrality of Asia to US foreign policy has thus led to the blurring and renewal of two distinctly 2oth-century terms ('American Pacific' and the 'American Century'), with the 2ist century being labelled as 'America's Pacific Century'.

Jeffrey Geiger

\section{References}

Aldrich, Robert (I990) The French Presence in the South Pacific, 1840-1940. Honolulu: University of Hawai'i Press.

American Asiatic Association (I925) Full page advertisement in Asia 25 (August): 709.

Bancroft, Hubert Howe (I9I2) The New Pacific. New York: The Bancroft Company.

Davidson, J.W. (I967) Samoa mo Samoa: The Emergence of the Independent State of Western Samoa. Melbourne: Oxford University Press.

Droessler, Holger (2013) 'Whose Pacific? US Security Interests in American Samoa from the Age of Empire to the Pacific Pivot', Pacific Asia Inquiry 4(I): 58-65.

Dudden, Arthur P. (I994) The American Pacific: From the Old China Trade to the Present. New York: Oxford University Press.

Herbert, Thomas Walter (I980) Marquesan Encounters: Melville and the Meaning of Civilization. Cambridge, MA: Harvard University Press.

Hiery, Joseph (I995) The Neglected War: The German South Pacific and the Influence of World War I. Honolulu: University of Hawai'i Press.

Hulme, Peter (2012) 'Remember the Mane: A Special Poetic Relationship, I895-I904', Kunapipi 34(2): 55-68. 
James, William (I972 [1900]) 'Letter to Senator G.F. Hoar' (II May), in Richard E. Welch, Imperialists us. Anti-imperialists: The Debate Over Expansionism in the 18gos. Itsaca, IL.: F.E. Peacock, pp. Io8-Iog.

Johnson, Donald D. and Gary Dean Best (1995) The United States in the Pacific: Private Interests and Public Policies, 1784-1899. Westport, CT: Greenwood Press.

LaFeber, Walter (1998 [1963]) The New Empire: An Interpretation of American Expansion, 1860-1898. Ithaca, NY: Cornell University Press.

Leff, David N. (I940) Uncle Sam's Pacific Islets. Stanford: Stanford University Press.

Lyons, Paul. American Pacificism: Oceania in the US Imagination. London: Routledge, 2006.

Melville, Herman (I994 [185I]) Moby-Dick. London: Penguin.

Melville, Herman (1996 [1846]) Typee: A Peep at Polynesian Life. London: Penguin.

Morgan, Howard Wayne (2003) William KcKinley and His America. Kent, $\mathrm{OH}$ : Kent State University Press.

Paolino, Ernest N. (I973) The Foundations of The American Empire: William Henry Seward and US Foreign Policy. Ithaca, NY: Cornell University Press.

Perry, John Curtis (1994) Facing West: Americans and the Opening of the Pacific. Westport, CT: Praeger.

Porter, Captain David (1822) Journal of a Cruise Made to the Pacific Ocean in the United States Frigate Essex in the Years 1812, 1813, and 1814 , vol. 2. New York: Wiley and Halstead.

Rafael, Vincent L. (2000) White Love and Other Events in Filipino History. Durham, NC: Duke University Press.
Rosenberg, Emily S. (1982) Spreading the American Dream: American Economic and Cultural Expansion, 1890-1945. New York: Hill and Wang.

Rowe, John Carlos (2000) Literary Culture and U.S. Imperialism: From the Revolution to World War II. Oxford: Oxford University Press.

Soja, Edward (1989) Postmodern Geographies: The Reassertion of Space in Critical Social Theory. London: Verso.

Subramani (1985) South Pacific Literature: From Myth to Fabulation. Suva: University of the South Pacific Press.

United States Government Accountability Office (I99I) 'US Personnel in the Pacific Theater' (released 20 August). Available at: http://www.gao.gov/products/NSIAD9I-I92 (accessed on Io January 20I4).

Welch, Richard E. (1972) Imperialists vs. Antiimperialists: The Debate Over Expansionism in the 18 gos. Itsaca, IL.: F.E. Peacock.

Wilson, Rob (2000) Reimagining the American Pacific: From South Pacific to Bamboo Ridge and Beyond. Durham, NC: Duke University Press.

Wrobel, David M. (1993) The End of American Exceptionalism: Frontier Anxiety from the Old West to the New Deal. Lawrence, KS: University of Kansas Press.

\section{Selected works}

Erskine, Charles (I985 [I89o]) Twenty Years Before the Mast: With the More Thrilling Scenes and Incidents While Circumnavigating the Globe Under the Command of the Late Admiral Charles Wilkes, 1838-1842. Washington, DC: Smithsonian Press.

Takaki, Ronald (1983) Pau Hana: Plantation Life and Labor in Hawai $i, 1835-1920$. Honolulu: University of Hawai'i Press. 